\title{
Characteristics of Cooperative Education and Internship in Aviation Management Programs
}

\author{
D. Scott Worrells \\ Southern Illinois University Carbondale
}

\begin{abstract}
Cooperative education and internship are separate and distinct means of providing students with a work-based learning experience. Traditionally speaking cooperative education is a means by which students acquire real work experience through actual employment that is similar, if not identical, to their intended career field. Internship traditionally exposes students to the working environment. Over time these differences have become blurred and in many cases the terms are used synonymously. The purpose of this study was to determine to what extent practitioners in Aviation Management (AVM) programs differentiate between cooperative education and internship. The study was delimited to: community colleges, colleges, and universities affiliated with the University Aviation Association (UAA) having AVM programs that participate in cooperative education and/or internship.
\end{abstract}

Carbondale (SIUC) AVM is a Baccalaureate degree program. The purpose of the AVM program is to prepare graduates for entry-level management positions in the aviation industry. Students enrolled in the AVM major are encouraged to complete the requirements of an aviation-related associate degree or to have equivalent licensing, aviation-related work experience, cooperative education experience, internship experience, or technical training (“Undergraduate Curricula,” 2006, p. 181).

In the NewMyer, Ruiz, and Rogers (2000) study of cooperative education and internship partnerships between U.S. airlines and aviationrelated university flight programs, the researchers compared and contrasted the "top 12 internship programs." Their study defined "cooperative education" and "internship" specifically in the context of an agreement between an industry sponsor and an academic institution's aviation program. The National Commission for Cooperative Education (NCCE) (as cited in NewMyer et al.) described cooperative education as:

... a structured educational strategy integrating classroom studies with learning through productive work experiences in a field related to a student's academic or career goals. It provides progressive experiences in integrating theory and practice. Co-op is a partnership among students, educational institutions and employers, with specified responsibilities for each party. (p. 113)
And, according to NewMyer et al.:

Internships involve spending a pre-arranged period of time working in a field of study or interest. The 1998 Southern Illinois University at Carbondale (SIUC) Undergraduate Catalog defines an aviation occupational internship as ...an unpaid internship position...performing duties and services in an instructional setting as previously arranged with the sponsoring work-site supervisor. (p. 113)

In July 1987, SIUC and United Airlines (UAL) signed a formal agreement to establish one of the first major airline-university internship agreements (NewMyer, Ruiz, \& Worrells, 1998). The purpose of such an internship, according to Spencer (1988), is to:

1. Develop additional resources for high quality flight officer candidates.

2. Improve the supply of qualified flight officer candidates.

3. Increase the number of qualified minority and female flight officer candidates.

4. Take advantage of the college and university system as a resource of the pilot of the future.

Internships that provide an opportunity to combine on-campus academic learning with professional work experience and that "bridge the gap" between the classroom and the world of work have become increasingly valuable to 
interns, participating institutions, and industries (Phillips, 1996). Internship activities have expanded from the initial flight operations internship where students are active in various and sundry administrative tasks to becoming familiar with flight crew training, customer relations, maintenance operations, and dispatch. Internships have also developed outside of the airline industry and are commonly conducted by aerospace manufacturers, airport authorities, education/training facilities, and fixed base operators (Schukert, 1993). In an earlier study by Thiesse, NewMyer, and Widick (1992), five basic types of internship were identified: (a) academic, (b) departmental rotation, (c) jobshadowing, (d) single department, and (e) specific task.

The numbers and types of industry sponsors have also expanded beyond the original SIUCUAL partnership (D. A. NewMyer, Personal Communication, 2003, December 5). Students regularly participate in either a flight and/or a non-flight internship. A representative listing of industry sponsors includes, but is not limited to:
1. Aerospace manufacturing companies
2. Aircraft maintenance companies
3. Airport administrators
4. Aviation consultants
5. Federal Aviation Administration
6. General aviation companies
7. Illinois Department of Transportation
8. National Transportation Safety Board
9. Professional aviation organizations

The diversity of internship activities in which students participate is not unlike those reported by Schukert (1993, May), who found that most interns work for government organizations or the airlines. In a study based upon a geographical distribution of 119 UAA members, Mitchell (2000), surveyed 17 universities, $14 \%$ of the UAA membership at that time, and found that:

1. Nine internship categories existed overall and that each school responding had an average of six internship programs.

2. The nine categories of internship were reported as: (a) major airlines, (b) general aviation, (c) airport authorities, (d) regional airlines, (e) aviation services, (f) corporate aviation (g) government, (h) aviation manufacturing, and (i) professional associations.

3. Airlines were the most consistent industry sponsors.

4. All institutional sponsors reported internship agreements.

5. Several institutional sponsors had established and staffed an internship office for student placement and coordination.

\section{REVIEW OF LITERATURE}

\section{The Evolution of Aviation Management}

The roots of present day Aviation Management programs can be traced back to the Civil Pilot Training (CPT) program of World War II (Strickler, 1993). At that time, the demand for pilots was so great that civilian institutions were called upon to supplement military training programs. After World War II and through the 1970s, the pathway to a career in aviation had been turned around and the military became the primary source of aviation professionals for the commercial aviation industry. By the middle of the 1980s, the military could no longer keep pace with the demand for aviation professionals. This trend continued and by 1995 civilian institutions had emerged as the primary source of personnel for commercial aviation. Not only had the source of personnel shifted, but it was also found that the most desirable personnel qualifications had expanded from technical skills to include administrative and managerial skills as well.

Military trained aviation professionals. The CPT program of World War II established the foundation for partnerships between colleges, the military, and the aviation industry. Established in 1939 and lasting until 1944, the CPT program was the largest pilot training program ever undertaken. It began with 13 colleges and 330 students who received college credit for ground school courses. By 1944, it had expanded to 1,132 colleges, with 1,460 private aviation contractors providing "for credit" flight instruction to 435,165 pilot candidates (Strickler, 1993, p. 17).

In the decades that followed World War II, the military established itself as a pathway to professional careers in the civil aviation 
industry. Military trained personnel were prime candidates for careers in the aviation industry due to their numbers and availability, experience, and qualifications. Another factor that made military aviators attractive prospects was that their experience and qualifications came at no cost to the civil aviation industry.

Collegiate aviation program Reliance on the military as a source of aviation personnel continued through the mid-1980s. From about 1985 through 1995, however, the military as a source of supply of aviation professionals was reduced by 40\% (Hansen \& Oster, 1997, p. 54). This reduction was due to: a drawing down of the military's force size and the success of military efforts to retain critical personnel. According to Kennedy (as cited in NewMyer, 1991), these two factors coincided with increasing retirements in the ranks of civilian aviation personnel. The cumulative effect was an increased demand for aviation professionals and a smaller pool of potential employees.

Lindseth (1996) found that increasing numbers of baccalaureate aviation programs in the United States were related to economical factors, increased air travel, and a decrease in the supply of aviation professionals from the military. The shift from the military to civilian sources of personnel and the natural attrition of experienced aviation personnel from the industry focused the search for qualified aviation professionals on colleges and universities. Recognizing that the pathway to a career in aviation had shifted from the military to the civilian sector, Karp (2000) suggested that it might be time for a fundamental change in collegiate aviation education. Oster stated: "As we look to the future, our committee concluded that collegiate aviation programs were likely to become the dominant path into the aviation industry, not only for pilots and aviation maintenance technicians, but for management as well” (as cited in Mitchell, n.d., p. 2). The end result was that the aviation industry would need to rely to a much greater extent on civilian sources for technical and administrative/managerial personnel.

The Emergence and Growth of Aviation Management Programs Aviation management degree programs began to emerge when it was recognized that highly technical aviation careers also demanded a certain degree of managerial skill. According to Fairbairn (1987): "Students graduating from aviation programs frequently move into careers that have a significant management component. As a result, aviation management courses have evolved in aviation curricula to prepare graduates for these positions” (p. 77). Fairbairn further noted that the objective of aviation management courses, "... should be to provide enough depth in the unique aspects of a particular field of aviation to enable the student to engage in critical analysis and problem solving in that field” (p. 77). Lastly, Fairbairn pointed out that:

... courses should be structured in a manner that allows students to integrate material and apply management skills. What is needed is ... to develop activities which will meet the objectives of these courses. Programs must be developed to allow direct observation of a students [sic] abilities in a managerial role. (pp. 77, 89)

In 1968, there were approximately 20 baccalaureate aviation education programs in the country. By 1996, there were 276 postsecondary education institutions in the United States offering non-engineering aviation programs. Of these, 70 offered baccalaureate degrees in administration/management disciplines: aviation administration, airport management, aviation maintenance management, and air traffic control. Each of these programs involved some form of flight education. There were six additional programs, however, that offered a non-flight AVM degree (Lindseth, 1996). In 2003, 114 postsecondary institutional members of the UAA reported that there were 72 AVM programs: 21 associates, 44 bachelors, and 7 masters (Williamson, 2003). Seven of these were reported as non-flight AVM programs.

The Council on Aviation Accreditation (CAA) has recognized the significance of stand alone AVM programs. The CAA Accreditation Guidelines (2003) specify that:

For baccalaureate degree programs, the Aviation Management option MUST consist of a minimum of 36 semester hours in a coherent sequence of business and 
aviation courses designed to prepare the student to function effectively as a manager in a selected segment of the aviation industry. The combination of business and aviation courses SHOULD be designed to provide breadth of understanding of basic business principles and a depth of understanding of the particular segment of the aviation industry. Each school is free to specify the area of preparation, but it MUST provide focus on a potential career field rather than be an extension of the general approach provided by the core. (p. 28)

\section{Cooperative education and Internship in Aviation Management}

Aviation-related partnerships between business and education began as maintenance apprenticeships. Gradually, they evolved to include cooperative education opportunities and internships in flight and management. Throughout this evolution, there were no accepted standards for these types of activities. Their definitions and applications were as diverse as the students, industry sponsors, and institutions that participated in them.

Cooperative education and internship have evolved in parallel with, and as significant components of, aviation management programs. As AVM programs gained acceptance and grew into separate baccalaureate degrees, cooperative education and internship became institutionalized as essential components of and have been major factors in AVM program maturation.

Cooperative education. In 1971, LaGuardia Community College established the first mandatory cooperative education requirement in aviation at a community college in the U. S. Enrollment in 1971 was 500 students. By 1998, it was recognized as a leader in cooperative education with one of the largest cooperative education programs in the country. Enrollment had grown to approximately 10,000 students, 2000 of whom participated in cooperative education and/or internship with over 300 industry sponsors. "Individual internships are often sought which relate to the student's course of study, and students attend seminars in which they study issues such as workplace cultures and career-building skills” (Bailey, Hughes, \& Barr, 1998, p. 14).

Soon after becoming a university in 1971, Embry-Riddle Aeronautical University (ERAU) developed a cooperative education program. The purpose, according to Howell and Scott (2001), was to develop students' professional and personal aspirations and to guide their life in the direction of a sound career. "Our goal was to be practical, motivating and distinctive and to serve students, alumni, faculty and staff, as well as industry" (Howell \& Scott). Participants were provided an opportunity to bridge the gap between the classroom and work environment and to earn credit hours toward an undergraduate/graduate degree.

The Northrop/California State University, Fullerton Invitational Program in Operations Management was established in 1983. This program allowed students to work within Northrop's Operations Department in a variety of areas during the summer. Northrop also maintained an active cooperative education program with other universities allowing students to alternate between work and study (McCarthy, 1984).

The applied research partnership program developed at Purdue University exemplifies how cooperative education and internship can be integrated within an AVM program. The program was initiated in 1996 in response to industry representatives who complained of a significant adjustment period for graduates entering aviation careers (Morton, Eiff, \& Lopp, 2001).

While aviation industry employers generally agree that aviation education programs are providing excellent foundational technical and managerial knowledge and skills, they continue to report that students lack confidence in applying their education during the initial phases of their aviation careers. Additionally, industry feedback often indicates that students lack comprehensive knowledge of aviation industry settings and processes. Graduates are generally reported to understand the concepts of problem solving, project management, team building and work analysis but demonstrate a 
weakness in applying those concepts within the context of their aviation work settings.

Internship Internship provides opportunity to combine on-campus academic learning with professional work experience and "bridge the gap" between classroom and the world of work are increasingly valuable to interns, participating institutions, and industry (Phillips, 1996). Internship activities have expanded from those in which the intern is actively involved in various and sundry administrative tasks within a flight operations environment to working in flight crew training, customer relations, maintenance operations, and dispatch. Internships have also developed outside of the airline industry and are commonly conducted by aerospace manufacturers, airport authorities, education/training facilities, and fixed base operators (Schukert, 1993).

Cooperative education and internship From 1971 throughout the 1990s, cooperative education and internship programs continued to evolve into an integral component of aviationrelated degree programs. However the lack of standardization, as previously noted, continued to persist. Accordingly, the definition of "internship" and "cooperative education" varies from campus to campus and department to department. "Internships" at one university reflect the definition of "co-op" at another (Allen, Kielbaso, \& Dirkx, 1999, p. 9).

Leasure and Stanley (2000) discussed cooperative education and internships in general terms. They differentiated between the two with the observation that "...the cooperative education process is more rigidly defined and therefore is less adaptable to innovation" and "... co-op students are receiving pay for their efforts and have the expectation of continued employment for the duration of their contracts" (p. 14). A noteworthy comparison made by NewMyer et al., is that:

The primary difference between an internship and a co-op is that internships are usually unpaid work experiences, while co-ops are salaried. Also, co-ops typically require that the student alternate between multiple periods of pre-arranged work assignments and semesters of traditional on-campus academic learning. (p. 113)

In 1999, the UAA Curriculum Committee convened to develop standard practices and procedures for the establishment and application of cooperative education and internship in aviation-related programs. The Internship Program Guidelines were published as a result of the committee's efforts. "This document sets forth representative guidelines and procedures that may be used in establishing intern programs for two- and four-year college students from aeronautical curricula with employers representing the public and the private sectors of aviation" (UAA, 1999, p. 1). The guidelines provide structure and at the same time provide flexibility in their application. For example:

... paid or unpaid opportunities for students to function in a typical 'on the job' environment where they can acquire knowledge and useful experience. The number of work hours required each week as well as the length of the internship period will vary depending on program design factors such as the academic schedule of students, number of hours student will be available for work, the grouping of hours, individual candidates' schedules, transportation requirements and type of work product. (p. 1)

\section{METHODOLOGY}

A descriptive research method that employed a self-report research instrument was used to collect data for the study. According to Best and Kahn (2003):

A descriptive study describes and interprets what is. It is concerned with conditions or relationships that exist, opinions that are held, processes that are going on, effects that are evident, or trends that are developing. It is primarily concerned with the present, although it often considers past events and influences as they relate to current conditions. (p. 114)

More specifically, survey research was used to identify and describe the perceptions of aviation management program representatives 
regarding the characteristics of cooperative education and internship.

\section{Subjects}

The point of departure for the study consisted of 114 institutional members of the UAA as listed in the Collegiate Aviation Guide (Williamson, 2003). The Guide contains an "Alphabetical Listing with Options and Degrees" offered by various colleges and universities that was analyzed to identify programs having an "Aviation Management/Airway Science Management” curriculum. Following the analysis, 77 institutional members were designated as having met the following definition of aviation management according to the U.S. Department of Education's (2000) Classification of Instructional Programs and which also participate in cooperative education and/or internship.

A program that prepares individuals to apply technical knowledge and skills to the management of aviation industry operations and services. Includes instruction in airport operations, ground traffic direction, ground support and flight line operations, passenger and cargo operations, flight safety and security operations, aviation industry regulation, and related business aspects of managing aviation enterprises. (para. 6, 49.0104)

The 77 UAA programs meeting this criterion were designated as the target population. To validate the population, a presurvey procedure was conducted as follows.

1. An e-mail letter of solicitation was sent to each of the 77 institutions, requesting information regarding the AVM curriculum, participation in cooperative education and/or internship activities, and a willingness to participate in the study. Descriptive information regarding the program and designation of a contact person to complete the survey were also requested. The e-mail messages were sent on October 19, 2004.

2. On October 20, 2004, 10 messages had been returned with the notation "reason: 550 Host unknown.” The 10 addresses were ultimately corrected via telephone contacts and searches of institutional web sites, after which the 10 e-mail messages were resent by October 25, 2004.

3. By November 3, 2004, 42 institutions had responded, 36 of which indicated a willingness to participate in the study. A second e-mail message was sent on November 4, 2004. The original message was supplemented with a statement indicating that this was a second attempt to solicit information. A deadline of November 10, 2004, was established at which time telephone calls would be made to those not responding as well as to those that had indicated "No Interest" to either of the preceding e-mail messages.

4. On November 12, 2004, follow-up telephone calls were initiated. Although frustrating at times, this effort proved to be worthwhile. In one instance a community college thought to have an AVM program reported that they did not, however, that same institution referenced another AVM program not previously identified. As a result the target population grew to 78 .

5. By the beginning of January 2005, information had been received from 78 institutions. Four institutions were eliminated because they did not have an AVM program and four others were eliminated because they did not participate in cooperative education and/or internship. As a result, the accessible population consisted of 70 institutions having AVM programs and which offer cooperative education and/or internship. Fifty-six of these are university level institutions and 15 are accredited by the Council on Aviation Accreditation.

\section{Instrumentation}

Information to develop the survey was drawn from three sources: (a) survey research instruments previously developed by Bargar, Fones, Lave, and Staley (1973); Bragg et al. (1995); Mason (1985); Raiola, Kibler-Hacker, 
Potter, and Reed (1991); and Thiesse et al. (1992), (b) relevant literature regarding cooperative education, internship, and other forms of work-based learning by Prather (1999), Ruiz (2003), and Schukert (1993, May), and (c) the author's knowledge and perceptions regarding work-based learning within aviation management programs.

Multiple drafts of the research instrument were developed over the course of several months. The final draft of the survey was completed in March 2005 after which the instrument was submitted to a jury for an analysis of content validity. Comments and suggestions from the validation panel were incorporated into a revised final draft.

To assess reliability of the instrument, a pilot test was conducted by 10 aviation management professionals representing universities or professional aviation organizations in April 2005. Comments and suggestions resulting from the pilot test were used to develop the final version of the instrument.

As a result of the validation panel review and the pilot test, the instrument was assumed to be valid and reliable. The research instrument was subsequently reviewed and approved for use by the Southern Illinois University Human Subjects Committee.

\section{Data Collection Procedures}

During the process of developing the survey instrument, it was determined that the most efficient method of gathering data would be an on-line survey. To accomplish this task, Instructional Support Services (ISS) in the Department of Library Affairs at Southern Illinois University Carbondale was contacted for assistance. The ISS staff recommended the use of a software program called "Surveys,"

It was developed at UIUC. It aids in the creation of online survey forms that can be installed on a central server for distribution over the web. Survey questions can be of many types, including multiple choice, Likert scale, short answer, or free text. Responses are sent to a database for collection and analysis. What it lacks in sophisticated control mechanisms it more than makes up in simplicity of use. ( $\mathrm{H}$.
Carter, personal communication, December 16, 2004)

A one hour orientation, followed by a brief question and answer session was provided by ISS personnel. The paper copy of the instrument was easily converted into an on-line survey with only a minimum of manual HTML coding required. Only one item required modification to accommodate a format limitation of the software.

The survey was disseminated to the 70 AVM program representatives via e-mail on May 31, 2005. The e-mail message included a hyper-link that allowed each participant to connect directly to the survey web site. The compatibility between the on-line survey and the paper copy is such that only a few minor problems were encountered by respondents. The first completed instrument was received on May 31, 2005, and the last was received on August 15, 2005.

\section{Treatment of the Data}

Analysis of raw data began soon after receiving the last survey. One advantage of an on-line survey is that raw data are readily compiled without having to manually code and enter the data. Conventional descriptive statistics were used to tabulate and analyze the data. Data interpretation was based upon logical and analytical means.

The questionnaire consisted of 12 categorical items designed to gather data on the perceptions of AVM representatives. The data gathered from the 12 questions were related to the perceived differences of cooperative education and internship.

\section{CHARACTERISTICS OF COOPERATIVE EDUCATION AND INTERNSHIP}

Cooperative education began in the early $1900 \mathrm{~s}$ as an alternate form of vocational/technical education in which students work full- or part-time at a paid job under the direction of a workplace supervisor. The purpose of the employment is to learn specific occupational skills on-the-job rather than in a school-based shop or laboratory. The cooperative education experience includes a written training agreement among the student, school representative, and employer and requires 
a training plan that lists specific objectives to be achieved. Cooperative education has generally been perceived as a very successful type of vocational/technical education at both the secondary and post-secondary levels.

The internship is a newer approach that became prominent on community college and university campuses in the 1960s in the more traditional academic areas. Internship is perceived as a way of providing students with practical experience and exposure to the workplace that is not achieved in a conventional classroom setting. Most interns work full- or part-time for a semester or less and may or may not receive compensation. Generally, the internship is less structured than cooperative education and may not require a training agreement and training plan.

Cooperative education and internship have always played an important role in aviation programs. Early on, cooperative education fulfilled a need by providing practical experience for those pursuing technicallyoriented aviation occupations. Aviation management programs evolved from a nontechnical option for professionally-oriented aviation occupations. Over time, AVM programs created an identity of their own separate and distinct from the more technical programs that prepare pilots, mechanics, dispatchers, air traffic controllers, and the like.

As AVM programs have evolved, so too has the application of cooperative education and internship. Both are used to provide AVM students with experiential learning opportunities. However, there is some anecdotal evidence which suggests that AVM program administrators and faculty often use the terms interchangeably and that traditional distinctions between cooperative education and internship may be diminishing.

The research instrument is designed to compare perceptions of AVM program representatives to traditional conceptions of cooperative education and internship. Twelve characteristics of cooperative education and internship were provided; with items $1,5,6$, and 10 being typical characteristics of cooperative education and items 2, 4, and 11 being typical characteristics of internship. Items 3, 7, 8, 9, and 12 can be associated with one or both.
The data is summarized in Table 1 and Table 2. The first table shows individual responses to each characteristic. For example, 51 individuals responded to the first item indicating that the characteristic is associated with 9 cooperative education programs, 25 internship programs, and 17 respondents indicate that it applies to both cooperative education and internship. An unusual and inexplicable facet of this data is that, although a total of 53 individuals completed the survey, the number of responses to individual items ranges from 28 to 53.

The more meaningful data are shown in Table 2 which allows a direct comparison between the characteristics of cooperative education and internship. This table was constructed by adding the number of frequencies for "both" to cooperative education and internship, for example, 17 responses for item one have been added to cooperative education and internship.

Overall, the data in Table 2 shows that the 12 characteristics of cooperative education and internship apply more to internship than to cooperative education. These findings are unexpected, particularly in relation to traditional characteristics of cooperative education. For instance, "learning occupational skills for employment," “alternating academic terms," "receiving compensation," "written training agreements," and "conventional letter grades" are associated more frequently with internship than with cooperative education. 
Table 1. Characteristics of Cooperative Education and Internship

Characteristic $\begin{gathered}\text { Cooperative } \\ \text { Education } \\ \text { Internship }\end{gathered} \underline{\text { Both }}$

1. The primary objective is to learn

occupational skills for employment.

9

f N

2. The primary objective is to gain

familiarity with the general work environment.

10

32

1153

3. Is a required component of the

AVM program.

6

16

1133

4. Typically one academic term in duration.

5

32

$15 \quad 52$

5. May alternate, for an academic term or more, between the campus and the work-site.

19

$9 \quad 41$

6. Participants receive compensation.

11

22

$10 \quad 43$

7. Written (training) agreements are required.

10

24

$13 \quad 47$

8. Training plans listing specific

objectives are required.

9

18

$13 \quad 40$

9. Specific course title(s) and catalog number(s) apply.

8

26

$16 \quad 50$

10. Conventional letter grades

(A, B, C, etc.) are assigned.

7

25

$10 \quad 42$

11. Pass/Fail (P/F) grades are assigned.

9

12

$7 \quad 28$

12. A specific number of credit hours may be earned.

7

25

$19 \quad 51$ 
Table 2. Direct Comparison of Cooperative Education and Internship Characteristics

Characteristic

Cooperative

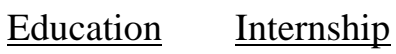

f $\% \quad f \quad \% \quad N$

1. The primary objective is to learn occupational skills for employment.

$\begin{array}{lllll}26 & 38.2 & 42 & 61.8 & 68\end{array}$

2. The primary objective is to gain familiarity with the general work environment.

$\begin{array}{lllll}21 & 32.8 & 43 & 67.2 & 64\end{array}$

3. Is a required component of the AVM program.

$\begin{array}{lllll}17 & 38.6 & 27 & 61.4 & 44\end{array}$

4. Typically one academic term in duration.

$\begin{array}{lllll}20 & 29.9 & 47 & 70.1 & 67\end{array}$

5. May alternate, for an academic term or more, between the campus and the work-site.

$\begin{array}{lllll}22 & 44.0 & 28 & 56.0 & 50\end{array}$

6. Student participants receive compensation.

$\begin{array}{lllll}21 & 39.6 & 32 & 60.4 & 53\end{array}$

7. Written (training) agreements are required.

$\begin{array}{lllll}23 & 38.3 & 37 & 61.7 & 60\end{array}$

8. Training plans listing specific objectives are required.

$\begin{array}{lllll}22 & 41.5 & 31 & 58.5 & 53\end{array}$

9. Specific course title(s) and catalog number(s) apply.

$\begin{array}{lllll}24 & 36.4 & 42 & 63.6 & 66\end{array}$

10. Conventional letter grades (A, B, C, etc.) are assigned.

$\begin{array}{lllll}17 & 32.7 & 35 & 67.3 & 52\end{array}$

11. Pass/Fail (P/F) grades are assigned.

$\begin{array}{lllll}16 & 45.7 & 19 & 54.3 & 35\end{array}$

12. A specific number of credit hours may be earned.

$\begin{array}{lllll}26 & 37.1 & 44 & 62.9 & 70\end{array}$ 
Conversely, the findings for traditional internship characteristics were expected. That is, characteristics dealing with "gaining familiarity with the work environment," "one academic term in duration," "pass/fail grades are assigned" are more frequently associated with internship than with cooperative education.

Regarding the remaining characteristics, the majority of respondents associate "a required component of the program," "written training agreements are required," "training plans are required," "course titles and catalog numbers apply," and "specific number of credit hours apply" with internship more so than with cooperative education, even though these characteristics have traditionally been associated equally with either cooperative education or internship.

For item 12, respondents were asked to indicate the range of credit hours allocated for cooperative education and internship. Interestingly, for both cooperative education and internship, 1 to 6 credit hours is the most frequently reported range by $19 \%$ and $30 \%$ of respondents, respectively. The highest reported range for either cooperative education or internship is 1-12 credit hours, as reported by $16 \%$ and $18 \%$ of respondents, respectively.

\section{SUMMARY AND CONCLUSIONS}

Aviation management is a degree program comprised of technical and non-technical coursework, initially functioning in a secondary role to the more technical curriculum designed for pilots, technicians, air traffic controllers, and the like. Aviation management has emerged as an autonomous degree program that prepares graduates for entry-level, non-technical careers in the aviation industry. As AVM has undergone a technical to non-technical transition, so too has the application of cooperative education and internship therein.

Cooperative education and/or internship has and continues to be, an important component of AVM. Although cooperative education and internship are distinctly different from one another, evidence has emerged that the distinctions are becoming less pronounced. Studies of cooperative education and internship suggest that the terms cooperative education and internship are often used synonymously, the terms are regularly reversed, and their traditional characteristics are frequently not understood or they are misapplied.

The application of cooperative education and internship parallels the technical to nontechnical transition that AVM programs have undergone. Initially, cooperative education provided technically-oriented AVM students an opportunity to acquire occupational skills for subsequent employment. More recently, internship has come into greater use to provide non-technical AVM students opportunities to observe and gain familiarity with prospective career fields.

The purpose of this study was to identify, analyze, and describe the characteristics of cooperative education and internship activities in post-secondary aviation management programs. The study was limited to colleges and universities affiliated with the UAA.

A self-developed research instrument was used in the study. A pre-survey was employed to identify 70 AVM programs having cooperative education and/or internships and who agreed to participate in the study. Survey participants were directed to an on-line questionnaire. Fifty three (75.7\%) provided input for analysis of the characteristics of cooperative education and internship. Data were analyzed using conventional descriptive statistics.

\section{RESULTS AND CONCLUSIONS}

To what extent do AVM programs that participate in cooperative education and/or internship differentiate between them?

Twelve traditional characteristics of cooperative education and internship; five associated with cooperative education, three associated with internship, and four associated with both made up the survey. Despite these distinctions, survey respondents more frequently associated all 12 characteristics with internship. Therefore, as the findings reveal, there is little or no distinction drawn between cooperative education and internship.

\section{SUGGESTIONS FOR FURTHER RESEARCH}

As a consequence of conducting this study, the following additional research is suggested or needed: 
1. The population of the study consisted of UAA member institutions. It would be interesting to investigate the characteristics of cooperative education and internship in institutions not affiliated with the UAA.

2. A focused survey should be conducted that targets leading or key innovators in the field regarding their attitudes, perceptions, and opinions on these specific issues: cooperative education and internship as a required component of AVM programs, and whether cooperative education should continue to be offered when internship is preferred and meets program objectives.

3. Case studies of successful, exemplar programs should be investigated to determine best practices which would serve as models to be adopted by other programs to improve and expand cooperative education and internship. 


\section{REFERENCES}

Allen, A., Kielbaso, G., \& Dirkx, J. M. (1999). The internship experience: Linking the university to the workplace (Catalog No. RR-2). East Lansing, MI: Michigan Center for Career and Technical Education. (ERIC Document Reproduction Service No. ED458359)

Bailey, T., Hughes, K., \& Barr, T. (1998, March). Achieving scale and quality in School-to-Work internships: Findings from an employer survey (MDS 902, Office of Vocational and Adult Education, U. S. Department of Education Grant No. V051A30003-97A/V051A30004-97A). Berkeley, CA: National Center for Research in Vocational Education. Retrieved July 14, 1998, from http://vocserve.berkeley.edu/AllInOne/MDS-902.html

Bargar, R., Fones, N., Lave, J., \& Staley, L. (1973). Program to operationalize a new training pattern for training evaluation personnel in education: Part F Report on design and evaluation of internship experiences. Columbus, $\mathrm{OH}$ : The Ohio State University Research Foundation. (ERIC Document Reproduction Service No. ED135811)

Best, J. W., \& Kahn, J. V. (2003). Descriptive studies: Assessment, evaluation, and research. In Research in education ( $9^{\text {th }}$ ed., pp.114-158). Boston, MA: Allyn and Bacon.

Bragg, D. D., Hamm, R. E., \& Trinkle, K. A. (1995, February). Work-based learning in two-year colleges in the United States (MDS 721, Office of Vocational and Adult Education, U. S. Department of Education Grant No. V051A30004-93A/V051A30003-93A). Berkeley, CA: National Center for Research in Vocational Education.

Council on Aviation Accreditation Incorporated. (2003, July). Accreditation standards manual: Form 101 (Rev. ed.). Auburn, AL: Author.

Department of Education: National Center for Education Statistics. (2000). Classification of instructional programs (CIP): 49.0104 Aviation/airway management and operations. Washington, DC: Author. Retrieved October 21, 2004, from http://nces.ed.gov/pubs2002/cip2000/ciplist.asp?CIP2=49

Fairbairn, G. R. (1987, Fall). Development of aviation management coursework. In W. D. Geibel (Ed.), University Aviation Association Fall Conference, (pp. 76-98). Auburn, AL: University Aviation Association.

Hansen, J. S., \& Oster, C. V. (Eds.). (1997). Taking flight: Education and training for aviation careers (National Research Council, U.S. Department of Education contract number EA9409001). Washington, DC: National Academy Press.

Howell, C. D., \& Scott, L. M. (2001, July). Aviation management: The view from below. Aviation Management Education and Research Conference, Proceedings [CD-ROM]. Montreal, Canada: Concordia University.

Karp, M. R. (2000, October). University aviation education: An integrated model. Collegiate Aviation Review, 18(1), 1-11.

Leasure, M., \& Stanley, D. (2000, Winter). Aviation students in industry: Strategies that enhance learning. Journal of Aviation/Aerospace Education and Research, 9(2), 13-16.

Lindseth, P. D. (1996). Identifying indicators of program quality in United States baccalaureate aviation programs. Dissertation Abstracts International, 57(03), 1046A. (UMI No. 9624672)

Mason, G. (1985, October). A national survey of internships in speech communication. Mt. Pleasant, MI: Central Michigan University. (ERIC Document Reproduction Service No. ED263648) 
McCarthy, J. F. (1984, Fall). Building public/private training: Partnerships with community colleges. Journal of Studies in Technical Careers, 6, 278-281.

Mitchell, F. G. (n.d.). Clipping the aviation industry's wings: The growing manpower shortage (UAA 145). Auburn, AL: University Aviation Association.

Mitchell, F. G. (2000, August). College survey report on internships. Auburn, AL: University Aviation Association.

Morton, B., Eiff, G., \& Lopp, D. (2001). Applied research partnerships: A success story. Aviation Management Education and Research Conference, Proceedings [CD-ROM]. Montreal, Canada: Concordia University.

NewMyer, D. A. (1991, October). Status report: An airline-university cooperative pilot career program. Collegiate Aviation Review, 2(1), 15.

NewMyer, D. A., Ruiz , J. R., \& Rogers, R. E. (2000). University flight operations internships with major airlines: Airline perspectives. Journal of Air Transportation World Wide, 5, 111-129.

NewMyer, D. A., Ruiz, J. R., \& Worrells, D. S. (1998, Winter). A pioneering university-airline flight internship program: A follow-up study on intern participants. Journal of Aviation/Aerospace Education and Research, 8(2), 28-33.

Phillips, W. (1996, November). Internships \& Co-ops: Collegiate programs that can make your aviation career take off. Flight Training, 8, 43-47.

Prather, C. D. (1999, Winter). Airport internships: Effectively structuring a departmental rotation internship. Collegiate Aviation Review, 17(1), 53-73.

Raiola, E. O., Kibler-Hacker, S., Potter, D., \& Reed, J. (1991). A study of the role and scope of experiential-learning at Unity College, Unity, Maine. (ERIC Document Reproduction Service No. ED333815)

Ruiz, J. R., Jr. (2003). Airline flight operations internships: Perceived impact in the pursuit of career goals. Dissertations Abstracts International, 64(08), 2858A. (UMI No. 3100773)

Schukert, M. A. (1993, May). Aviation career waypoints: A descriptive roster of cooperative education-supported non-engineering collegiate aviation programs in the U.S. Opelika, AL: University Aviation Association.

Spencer, K. (1988). UAL working relationships with aviation colleges [Brochure]. Denver, CO: United Airlines.

Strickler, M. K. (1993, June). Manpower needs in aviation. In First Annual Aviation Education Forum. Tomorrow's needs; Today's challenges (pp. 17-20). Washington, DC: The National Press Club.

Thiesse, J. L., NewMyer, D. A., \& Widick, L. (1992). FBO and airport internships for university aviation students: Benefits for students, universities, and the aviation industry. Journal of Studies in Technical Careers, 14, 253-264.

Undergraduate curricula and faculty. (2006, September). In Southern Illinois University Carbondale, undergraduate catalog, 2006-2007, 47(2), pp. 109-541.

University Aviation Association Curriculum Committee: Aviation education for the $21^{\text {st }}$ Century. (1999). Internship program guidelines. Auburn, AL: University Aviation Association.

Williamson, C. (Ed.). (2003). Collegiate aviation guide: Reference of college aviation programs. Auburn, AL: University Aviation Association. 